\title{
Association of Symptomatic Human Infection with Toxoplasma gondii with Imbalance of Monocytes and Antigen-Specific T Cell Subsets
}

\author{
Ivo Sklenar, Thomas C. Jones, Sefik Alkan, \\ and Peter Erb
}

\author{
From the Institute for Microbiology and Hygiene, University \\ of Basel; the Pharmaceuticals Division, Ciba-Geigy, Basel, \\ Switzerland; and the Division of International Medicine,
} Cornell Medical College, New York, New York
Infection with the coccidian protozoan Toxoplasma gondii causes no illness in most individuals. In about one of five infected individuals, various degrees of fatigue, malaise, fever, and lymph node enlargement are recorded [1]. These subjects recover without residual signs of disease; this distinguishes them from those with documented immune deficiency, in whom toxoplasmosis is often severe and even fatal [2]. It has also been noted that evidence of cellular immune response to toxoplasma antigens is delayed in appearance in some patients, compared with the kinetics of response to other antigens $[1,3,4]$. In an effort to understand better immune responses during acute symptomatic infection, we examined total $T$ cell subsets and toxoplasma antigen-induced $T$ cell subsets during toxoplasmosis.

Received for publication 22 May 1985 and in revised form 12 August 1985.

Informed consent was obtained from all human subjects studied.

This work was supported by grant 3.016.-0.84 from the Swiss National Science Foundation.

We thank Martin Wesp (Ciba-Geigy, Basel, Switzerland) for help with the Cytofluorograph analyses and Danielle Rieder for technical assistance.

Please address requests for reprints to Dr. Ivo Sklenar, Institute for Microbiology and Hygiene, University of Basel, Petersplatz 10, CH-4003 Basel, Switzerland.

\section{Subjects and Methods}

Subjects. A total of 22 individuals was studied. $T$ cell surface markers of peripheral blood lymphocytes (PBLs) were studied in 19 individuals with use of monoclonal antibodies and a Cytofluorograph ${ }^{\circledR}$ (Ortho Instruments, West Wood, Mass). According to the history of infection by $T$. gondii, three groups of subjects were defined. Six noninfected individuals (mean \pm SD age, $29 \pm 11$ years) were compared with five chronically infected individuals (mean \pm SD age, $33 \pm 7$ years) and eight patients with recent symptomatic toxoplasmosis (mean \pm SD age, $26 \pm$ 6 years).

The noninfected individuals were negative for $\operatorname{IgG}$ antibody to Toxoplasma by the immunofluorescence test at a serum dilution of 1:5. The chronically infected individuals were positive for IgG (mean titer, 1:300), were negative for IgM by conventional indirect immunofluorescence test, and had had no clinically manifest toxoplasmosis in the past. All the subjects with recent symptomatic toxoplasmosis had lymphadenopathy of more than one week in duration, and seven of the eight also had elevated temperatures (37-38 C) and malaise. In each of these individuals, high or rising titers of IgG antibodies to Toxoplasma and a titer of IgM antibodies of $\geqslant 1: 50$ were demonstrated by the immunofluorescence test. 
These subjects reported fluctuations in lymph node size for up to six months after infection.

Toxoplasma antigen-specific $T$ cell lines were generated from five subjects. The two designated by A had a history of recent symptomatic toxoplasmosis. Subject A1 was a 22-year-old man with lymphadenopathy of two weeks in duration, elevated temperature, and malaise who was positive for IgM antibody to Toxoplasma and had a titer of IgG antibody of 1:3,200 by the indirect immunofluorescence test. Subject A2 was a 36-year-old woman with a history of a short period of fever, followed by malaise and fatigue, associated with submandibular lymphadenopathy that progressed to generalized lymphadenopathy in the cervical, axillary, and inguinal regions. The enlarged lymph nodes persisted for four months. The titer of IgM antibody to Toxoplasma was $1: 64$ and that of $\operatorname{IgG}$ antibody was $1: 4,000$. This patient was chosen for study even 21 months after infection because she was one of those rare individuals without known underlying immunodeficiency who develop severe toxoplasmosis. Two subjects designated by $\mathbf{B}$ had no history of clinical illness, no IgM antibody to Toxoplasma by immunofluorescence, and low titers of IgG antibody (1:160 and $1: 320$, respectively). One asymptomatic 52 -year-old subject designated $\mathrm{C}$ had had Hodgkin's disease nine years ago (stage IIA). The excision biopsy specimens of his bilateral cervical lymphomas were macroscopically characteristic of tumor. Histological examination showed malignant cells of Hodgkin's disease, Sternberg-Reed cells, and lymphocytic depletion. He was treated with irradiation (4,400 rad; model Linac SL 75/5; Philips, Crawley, England) and chemotherapy (vinblastine, lomustine, prednisone, and procarbazine), and he has been in full remission for six years. The Sabin-Feldman dye test was first positive nine years ago (titer, 1:4,000), but CF antibodies were absent. Six years later the titer of IgG antibody was $1: 6,000$, and it was elevated at a titer of 1:25,600 at the time of the present study.

Cytofluorometry analysis of PBL subsets. PBLs from all patients were isolated by centrifugation with a gradient of Ficoll-Paque ${ }^{\circledR}$ (Pharmacia, Uppsala, Sweden). Erythrocyte-rosette enrichment was not performed so that studies of non-T lymphocytes (natural killer/killer [NK/K] cells) [5] could be done as well. The yield of T cells was $60 \%-76 \%$, which is comparable to that of the buffy coat technique [6]. After washing, $1.5 \times 10^{6} \mathrm{PBLs}$ were maintained for $45 \mathrm{~min}$ in ice with monoclonal antibodies Leu 3a (Becton-Dickinson, Mountain View, Calif) or OKT 4 (Ortho Diagnostic Systems, Raritan, NJ), antibody to $\mathrm{T} 4$ cells and helper/inducer $\mathrm{T}$ cell marker, respectively; Leu $2 b$ (Becton-Dickinson) or OKT 8 (Ortho), antibody to T8 cells and cytotoxic/suppressor cell marker, respectively; and antibody to TQ1 (Coulter Immunology, Hialeah, Fla), a marker of T cell suppressor subsets [7]. After washing with an excess of HEPES-buffered modified Eagle's medium, the cells were incubated with FITC-conjugated goat antibody to mouse immunoglobulin (BectonDickinson). After further washing the samples were resuspended in PBS without $\mathrm{Mg}^{++}$and $\mathrm{Ca}^{++}$and analyzed in a Cytofluorograph ${ }^{\circledR}($ model $50 \mathrm{HH}$; Ortho Instruments, West Wood, Mass) combined with a computer (model 2150; Ortho Instruments). By excitation of the cells with argon laser light at a wavelength of $488 \mathrm{~nm}(500 \mathrm{~mW}), 90^{\circ}$ scatter, forward narrow-angle scatter, and green fluorescence could be measured simultaneously. The numbers of lymphocytes were counted in the lymphocyte cluster of the scatter cytogram (figure 1), and the numbers of immunoflourescent cells were recorded. Gating was kept identical in the samples from each subject. Dead cells and debris were eliminated from the scatter of fluorescence analysis by electronic gating out of cells with low scatter signals. Viability of cells was $>90 \%$ by exclusion of ethidium bromide. Background fluorescence obtained with the FITC conjugate was subtracted. The percentage fluorescence acquired from 30,000 cells and the total lymphocyte count from the whole blood were used to calculate the absolute number of different cell types.

In addition, in four individuals (two acute symptomatic subjects and two controls) the cells of the lymphocyte cluster were characterized with use of staining with OKT 3 (for pan T cell), OKT 4, OKT 8 (all from Ortho), and antibody to HLA-DR (Becton-Dickinson; for monocytes and B cells). The contents of the Leu 7/HNK 1-positve cells and the cells showing simultaneous green (T8 positive) and red (Leu 7 positive) fluorescence in the lymphocyte cluster of these four individuals were determined with use of dual laser flow cytofluorometry. In eight individuals (five acute symptomatic subjects and three controls), analysis with Leu 7 (NK/K cell marker) was performed. Texas Red-avidin (E.Y. Labs, San Mateo, Calif) was used to develop biotinconjugated antibody to HLA-DR or antibody to Leu 7 on the lymphocyte surface. The cells were then analyzed for the presence of red fluorescence. In three 

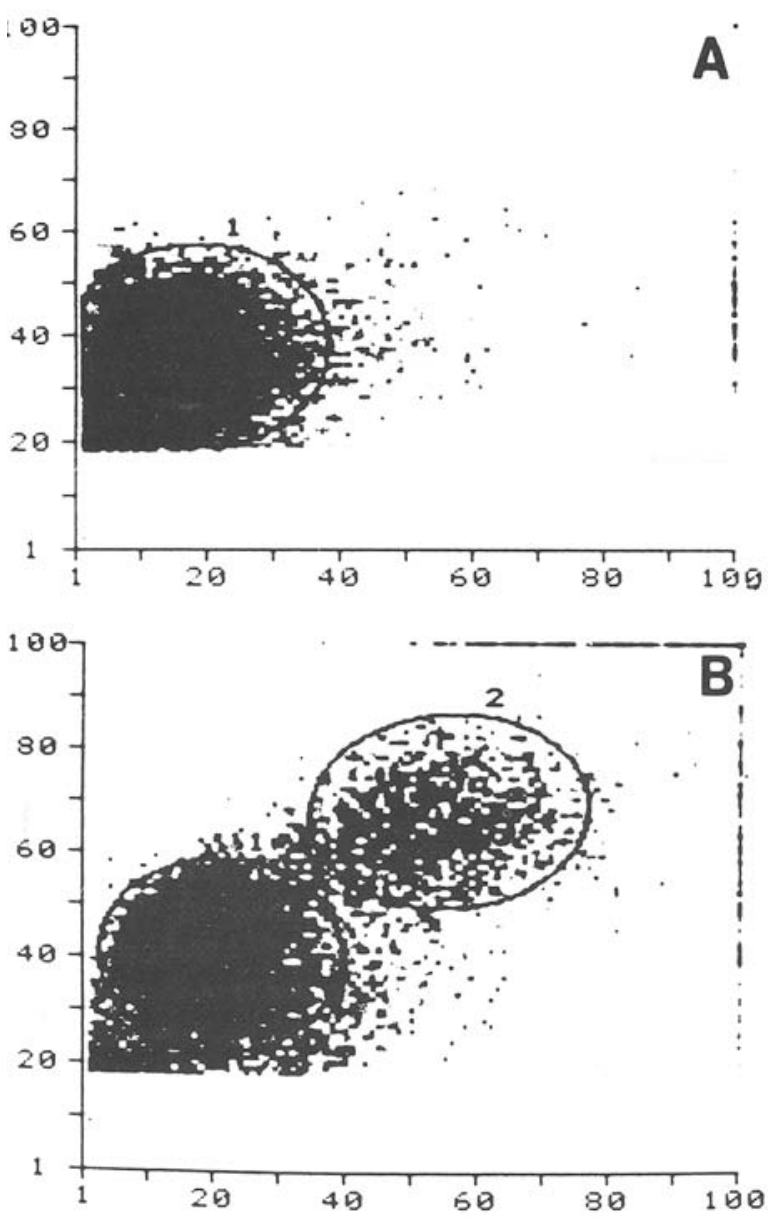

Figure 1. Laser light scatter cytogram of 30,000 peripheral blood mononuclear cells: $(A)$ cells originating from a noninfected control and $(B)$ cells from a subject with acute symptomatic toxoplasmosis. Forward narrow-angle scatter is shown on the ordinate, with $90^{\circ}$ scatter on the abscissa. Analysis with monoclonal antibodies of regions 1 and 2 showed that they consisted predominantly of lymphocytes and monocytes.

patients the cells of the monocyte cluster (figure 1B, region 2) were analyzed with use of monoclonal antibody Leu M3 (monocyte marker) and FITC-conjugated goat antibody to mouse immunoglobulin (Becton-Dickinson).

Toxoplasma-specific $T$ cell lines. Media. Dulbecco's modified Eagle's medium with addition of antibiotics and amino acids was used [8]. Pooled, heatinactivated human type $\mathrm{AB}$ serum was added in a $10 \%$ concentration. $T$ cell lines were cultured and expanded with use of medium conditioned with $10 \%$ crude human interleukin-2 prepared as described previously [9]. In brief, leukocytes $\left(4 \times 10^{6} / \mathrm{ml}\right)$ from the buffy coat of a freshly donated unit of blood (500 ml with acid citrate-dextrose anticoagulant) were stimulated with $50 \mu \mathrm{g}$ of phytohemagglutinin (PHA; GIBCO, Grand Island, NY) $/ \mathrm{mI}$ and $2 \times 10^{5}$ 24-hr-old allogeneic PHA-induced PBL blasts/ $\mathrm{ml}$ in Dulbecco's and alpha medium (1:1; GIBCO) and 2\% human type AB serum. After $36 \mathrm{hr}$ the supernatants were harvested, sterile filtered, and tested on PHAinduced blasts for promotion of $\mathrm{T}$ cell growth and DNA synthesis.

Generation of toxoplasma-specific $T$ cell lines. Soluble antigen was prepared from the RH strain of T. gondii as previously described [10]. All five subjects studied were pretested in an eight-day lymphocyte transformation assay with the antigen to determine the optimal dose for maximal proliferation. In general, this dose was $10-100 \mu \mathrm{g} / \mathrm{ml}$. PBLs, $2 \times 10^{6} / 2$ $\mathrm{ml}$, from each subject were incubated for eight days with two doses of antigen $(10$ and $100 \mu \mathrm{g} / \mathrm{ml})$ in 24 well culture plates (Costar, Cambridge, Mass). After eight days the cells were harvested, pooled, and resuspended in fresh conditioned medium. The cells were expanded in culture plates (Costar) by renewal of the medium every three days. After two weeks in culture the cells were tested for toxoplasma antigen-specific proliferation. Flat-bottom 96-well plates (Micro Test II ${ }^{\circledR}$; Falcon, Oxnard, Calif) were incubated with $1.5 \times 10^{5}$ irradiated $(3,000 \mathrm{rad})$ autologous PBLs in medium with $10 \%$ type AB serum for $1 \mathrm{hr}$. The nonadherent cells were harvested, the wells were washed with PBS, and the recovered cells were counted. By this method the number of adherent cells (ACs) was calculated and found to be $20 \%-30 \%$ of the original number of plated cells. ACs in the wells served as antigen-presenting cells. The $T$ cell lines $\left(10^{5}\right.$ per well in duplicate wells) were cultured for $72 \mathrm{hr}$ in the presence of ACs plus 100 $\mu \mathrm{g}$ of toxoplasma antigen $/ \mathrm{ml}, 10 \mu \mathrm{g}$ of tetanus toxoid (Institut Sẻrothérapique et Vaccinal Suisse Berne, Bern, Switzerland) $/ \mathrm{ml}$, or ACs alone. For the last $8 \mathrm{hr}$ of culture the cells were pulsed with $0.25 \mu \mathrm{Ci}$ of $\left[{ }^{125} \mathrm{I}\right]$ deoxyuridine per well and harvested (Titertek ${ }^{\circledR}$ cell harvester; Flow Laboratories, Irvine, Ayrshire, Scotland). The number of $\mathrm{cpm}$ was determined in a $\gamma$ counter (Packard Instrument Co., Downers Grove, III). Only when toxoplasma antigen-specific proliferation was documented was the distribution of the T cell markers T4, T8, and TQ1 of a line studied. The indirect immunoflouroescence method was used. T cells $\left(10^{6}\right)$ were reacted with the monoclonal antibodies for $45 \mathrm{~min}$ in ice, washed, 
and reacted with FITC-conjugated goat antibody to mouse immunoglobulin. After washing, the percentage of fluorescent cells was determined by counting 200 cells with the immunoflouorescence microscope.

Limiting-dilution cultures. Toxoplasma-specific $T$ cell sublines were obtained from one of the patients with recent toxoplasmosis (A2) and one of the individuals with chronic infection (B2) according to previously described techniques [8]. Microtiter plates with irradiated autologous $\mathrm{AC}$ feeder layers were used. Toxoplasma antigen $(50 \mu \mathrm{g} / \mathrm{ml})$ and medium conditioned with $5 \%$ interleukin-2 were used in limiting-dilution cultures of 100,10 , and 1 cells per well. Only the dilution containing 10 cells per well showed a favorable cloning efficiency $(13 \%$ of wells positive) and allowed selection of sublines of both T4- and T8-enriched cells. The proliferative responses to toxoplasma antigen of the T4 and T8 sublines were studied with use of the same protocol described above.

Production of $\gamma$ interferon (IFN-y) by Toxoplasma-specific $T$ cell lines and sublines. Irradiated ACs, $1 \times 10^{5}$, and $5 \times 10^{5} \mathrm{~T}$ cells were incubated with $50 \mu \mathrm{l}$ of toxoplasma antigen $/ \mathrm{ml}$, purified protein derivative (Institut Sérothérapique et Vaccinal Suisse Berne), or PHA. After $72 \mathrm{hr}$ the supernatants were harvested, filtered, and frozen. The supernatants were tested for IFN in a CPE inhibition assay [11] with use of WISH cells $\left(3 \times 10^{4}\right.$ per well). In brief, WISH cells were incubated for $24 \mathrm{hr}$ with supernatants titrated in threefold dilutions and then infected with Mengo virus ( $800 \mathrm{pfu}$ ). The antiviral IFN- $\gamma$ activity was measured as the dilution of the supernatant that prevented $50 \%$ of the CPE. The supernatants were compared with an IFN- $\gamma$ standard obtained from Dr. S. Grossberg (Department of Microbiology, Medical College of Wisconsin, Milwaukee), and the concentration was recorded in $\mathrm{U} / \mathrm{ml}$. The IFN- $\gamma$ in the supernatants was demonstrated to be acid labile by treatment at pH 2.5 .

Statistical methods. The $t$ test statistics were performed, and the correlation coefficient was calculated.

\section{Results}

Analysis of peripheral blood mononuclear cells according to size. Figure $1 \mathrm{~A}$ is the cytogram of cells from a control, noninfected individual. Figure 1B, a cytogram of cells from a subject with acute symptomatic toxoplasmosis, shows two cell populations markedly different from those of the control individual with regard to laser light scatter characteristics. The region designated by 1 has been identified previously as a lymphocyte cluster, and region 2 has been identified as a monocyte cluster [6]. Six of eight of our symptomatic subjects and only one of six controls showed increased numbers of cells in region 2. To evaluate cells in this cluster, the distribution of cells with the markers Leu M3, T8, and $\mathrm{T} 4$ in both regions was studied in three subjects. Their ages were 28,20 , and 33 years, and they had been infected two, five, and six months ago. In these individuals $16.1 \% \pm 2.3 \%$ cytofluorometrically screened cells were found in region 2, comprising 67\%-75\% Leu M3-positive cells (monocytes), $16 \%-30 \%$ T 8 -positive cells, and $0 \%-7 \%$ T4-positive cells, depending on fluorescence intensity gating.

Region 1 (the lymphocyte cluster) was studied in two subjects with symptomatic toxoplasmosis (23 and 31 years of age, infected two months ago) and two noninfected controls ( 23 years of age) with use of OKT 3, 4, and 8 and antibody to HLA-DR (table 1). The number of total $T$ cells (T3 positive) in the lymphocyte cluster ranged from $60 \%$ to $76 \%$. In patients with symptomatic toxoplasmosis, the percentage of T4-positive (helper marker) cells was slightly lower, and the percentage of T8-positive (cytotoxic suppressor marker) cells was slightly higher in the lymphocytes clustered in region 1 , similar to the alterations seen in region 2 , and the absolute numbers of T8-positive cells were greater (see below). The number of HLA-DR-positive (B cells and monocytes) cells was not different in patients and controls in region 1 . The numbers of cells showing the Leu 7/HNK $1(\mathrm{NK} / \mathrm{K})$ marker as well as the dual T8 and Leu 7 marker were increased in the patients. This observation was confirmed by additional analysis of three patients (see below).

T8-, TQI-, and Leu 7-positive cells in peripheral blood of patients. Table 2 shows characteristics of the individuals studied and summarizes the results of peripheral $\mathrm{T}$ cell subsets contained in the lymphocyte cluster analyzed by three monoclonal antibodies with use of flow cytofluorometry. The absolute numbers of T8-positive cells $/ \mathrm{mm}^{3}$ were significantly higher $(P<.001)$ in individuals with recent toxoplasmosis (one to six months ago) than in chronically infected individuals and in noninfected controls.

The T4/T8 cell ratio was significantly lower in subjects with recent toxoplasmosis compared with chronically infected and noninfected individuals $(P$ 
Table 1. Analysis of the lymphocyte cluster.

\begin{tabular}{|c|c|c|c|c|c|c|}
\hline \multirow[b]{2}{*}{ Individuals studied } & \multicolumn{6}{|c|}{ Percentage of fluorescent cells } \\
\hline & $\mathrm{T} 3+$ & $\mathbf{T} 4+$ & $\mathrm{T} 8+$ & HLA-DR + & Leu $7+$ & Leu $7+/ \mathrm{T} 8+$ \\
\hline \multicolumn{7}{|c|}{ Symptomatic toxoplasmosis } \\
\hline 1 ( 8 weeks ago) & 68.8 & 25.1 & 41.4 & 5.2 & 26.3 & 18.8 \\
\hline 2 (10 weeks ago) & 64.5 & 18.4 & 32.0 & 3.5 & 14.8 & 11.1 \\
\hline \multicolumn{7}{|l|}{ No infection } \\
\hline 1 & 60.4 & 32.9 & 31.5 & 4.9 & 10.7 & 9.0 \\
\hline 2 & 76.0 & 63.4 & 16.5 & 7.1 & 7.6 & 5.4 \\
\hline
\end{tabular}

NOTE. The cells were analyzed with use of antibodies to lymphocyte surface antigens: $\mathrm{T} 3$ (pan $\mathrm{T}$ cell marker), T4 (helper cell marker), T8 (cytotoxic/suppressor cell marker), HLA-DR (B cells and monocytes), and Leu 7/HNK 1 (NK/K cell marker). Leu 7/T8-positive cells were detected by dual laser cytofluorometry for simultaneous green and red fluorescence.

$<.001$ and $P<.01$, respectively). This difference was not due to decreased numbers of T4-positive (helper/inducer) cells, which did not differ significantly among all three groups of individuals. In addition, the number of cells positive for TQ1 marker (the marker of certain suppressor cell subsets) [7, 12] did not vary in the three groups. Absolute mean \pm SD numbers of TQ1-positive cells $/ \mathrm{mm}^{3}$ were 643 \pm 331 in recent toxoplasmosis $(n=3), 576 \pm 399$ in chronic infection $(n=5)$, and $560 \pm 231$ in controls $(n=3)$.

The number of Leu 7-positive (NK/K) cells in five patients with acute toxoplasmosis (mean \pm SD age, $27 \pm 5$ years) was significantly increased compared with three noninfected controls (mean $\pm \mathrm{SD}$ age, $32 \pm 15$; table 2 ). This increase was not due to the age of the subjects noted in the normal population [5] because ages in the two groups were comparable. Peripheral blood monocytes in acute toxoplasmo- sis. The light scatter cytogram suggested increased numbers of monocytes in persons with acute symptomatic toxoplasmosis. This proposal was confirmed by analysis of the differential blood counts from all patients studied. Acutely infected patients had 631 \pm 203 monocytes $/ \mathrm{mm}^{3}(9.4 \% \pm 2.9 \%)$, those chronically infected had cell counts of $516 \pm 248$ $(7.2 \% \pm 2.8 \%)$, and controls had cell counts of 402 $\pm 177(6.2 \% \pm 1.9 \%)$, results indicating significant monocytosis $(P<.05)$ in acutely infected patients.

Time course of changes in monocytes and T8positive cells during acute infection. Monocyte levels were increased during the first two months after infection but reached normal levels by five to six months (figure 2). There was a significant inverse correlation between the absolute number of monocytes and the time after infection $(y=-91.6 x+$ $906, r=-.89, P<.01$ ). In contrast, T8-positive lymphocyte numbers were increased from the earliest

Table 2. Characterization of subjects and their PBL subpopulations.

\begin{tabular}{|c|c|c|c|c|c|c|}
\hline \multirow[b]{2}{*}{ Individuals studied } & \multirow{2}{*}{$\begin{array}{c}\text { Age } \\
\text { (years) }\end{array}$} & \multirow{2}{*}{$\begin{array}{l}\text { Mean serum titer } \\
\text { of IgG antibody }\end{array}$} & \multicolumn{4}{|c|}{ Absolute cell number $/ \mathrm{mm}^{3}$} \\
\hline & & & $\mathrm{T} 4+$ & $\mathrm{T} 8+$ & Leu $7+$ & $\mathrm{T} 4 / \mathrm{T} 8$ \\
\hline $\begin{array}{l}\text { Acute symptomatic } \\
\text { toxoplasmosis }(n=8)\end{array}$ & $26 \pm 6$ & $1: 4,200$ & $\begin{aligned} 628 & \pm 242 \\
(23.4 & \pm 10)\end{aligned}$ & $\begin{array}{l}988 \pm 190 \\
(37 \pm 9)\end{array}$ & $\begin{aligned} 693 & \pm 329 \\
(28.4 & \pm 11)^{*}\end{aligned}$ & $0.7 \pm 0.3$ \\
\hline $\begin{array}{l}\text { Chronic asymptomatic } \\
\text { infection }(n=5)\end{array}$ & $33 \pm 7$ & $1: 300$ & $\begin{aligned} 680 & \pm 253 \\
(30.4 & \pm 14)\end{aligned}$ & $\begin{array}{l}437 \pm 241 \\
(19 \pm 8)\end{array}$ & NT & $1.7 \pm 0.5$ \\
\hline $\begin{array}{l}\text { Noninfected } \\
\text { controls }(n=6) \\
\end{array}$ & $29 \pm 11$ & 0 & $\begin{array}{l}894 \pm 445 \\
(42 \pm 11.2) \\
\end{array}$ & $\begin{aligned} & 517 \pm 167 \\
&(25.3 \pm 7) \\
&\end{aligned}$ & $\begin{array}{l}212 \pm 15 \\
(11 \pm 3)^{\dagger} \\
\end{array}$ & $1.8 \pm 1.0$ \\
\hline
\end{tabular}

NOTE. Data are mean \pm SD values (percentages as indicated). Subjects with acute symptomatic toxoplasmosis (AS) had been infected three months (range, one to six months) previously, whereas those with chronic asymptomatic infection (CA) had been infected many years previously. $P$ values for comparisons were obtained with use of $t$ test statistics: for T4 + , not significant for AS vs. $\mathrm{CA}$ and AS vs. noninfected individuals (N); for T $8+, P<.001$ for AS vs. CA and AS vs. N; for Leu $7+, P<.05$ for AS vs. N; and for T4/T8, $P<.001$ for AS vs. CA and $P<.01$ for AS vs. N. Not tested $=$ NT.

$* n=5$.

$\dagger n=3$. 

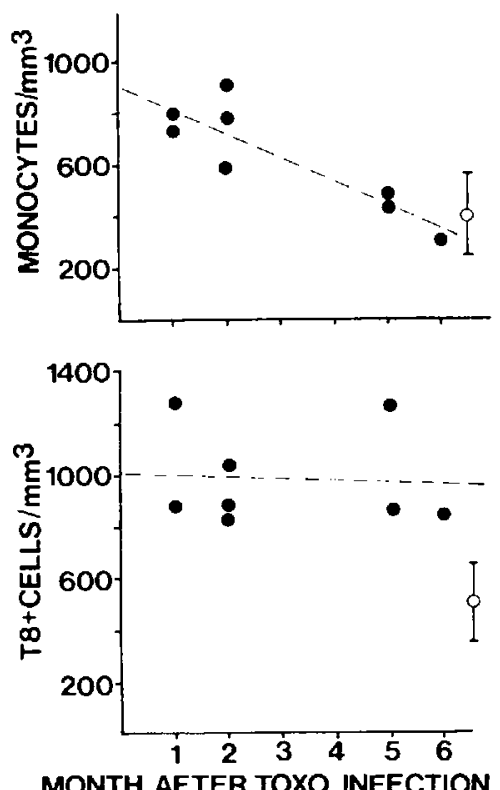

Figure 2. Alterations in numbers of the circulating monocytes and T8-positive lymphocytes in eight subjects with acute symptomatic toxoplasmosis in relation to time (months) after infection. Absolute numbers of cells $/ \mathrm{mm}^{3}$ of blood are shown. The mean \pm SD (bars) values from six noninfected individuals are also shown (O). Chronically infected patients showed the same values for counts of monocytes $\left(516 \pm 248\right.$ cells $\left./ \mathrm{mm}^{3}\right)$ and T8-positive cells $\left(437 \pm 241\right.$ cells $/ \mathrm{mm}^{3}$ ). Regression analysis (by the least squares method) is depicted by the dotted lines. A significant inverse correlation was found for monocytes $(r$ $=-.89, P<.01$ ) but not for T8-positive cells.

period after infection up to six months after infection and did not show a significant decline during the study period.

T8- and TQI-positive subsets in Toxoplasmaspecific $T$ cell lines. T cell lines induced from PBLs with use of soluble toxoplasma antigen that proliferated specifically on restimulation with antigen and syngeneic ACs were studied with use of monoclonal antibodies and indirect immunofluorescence. $T$ cell lines obtained from two recently infected and clinically ill individuals (Al, with illness two months ago, and A2, with illness 21 months ago) contained higher numbers of T8-positive (suppressor/cytotoxic) and TQ1-positive (suppressor subsets) cells than lines from chronically infected individuals $B 1$ and $B 2$, with no history of lymphadenopathy and fever (table 3 ).

Subject Al, studied for the first time two months after onset of symptoms, had a T4/T8 cell ratio in peripheral blood of 0.5 , and the $T$ cell lines showed increased proliferation of antigen-specific T8-positive cells $(62 \%)$. At five months after infection, the T4/T8 cell ratio was still low (0.6). Subject A2, studied 21 months after infection with Toxoplasma, which caused an illness of four months in duration, had a normal ratio of peripheral T4/T8 cells (2.2), but $\mathrm{T}$ cell lines still showed predominantly Toxoplas$m a$-specific T8-positive cells $(70 \%)$ when induced in vitro by antigen. This observation was in contrast to the behavior of $\mathrm{T}$ cell lines obtained from the chronically infected individuals B1 and B2, who had normal peripheral $T$ cell subset ratios (1.1 and 2.0) and whose lines showed lower numbers of T8positive cells $(30 \%-40 \%)$.

In addition, one individual with Hodgkin's disease was studied (subject $\mathrm{C}$ ). This subject demonstrated very low numbers of Toxoplasma-induced T8positive cells in $\mathrm{T}$ cell lines and very high serum titers of IgG antibody to Toxoplasma. This pattern of response is unusual and distinct from that of subjects with recent symptomatic toxoplasmosis, who had no other known underlying disease, and that of chronically infected but otherwise healthy individuals.

Proliferation and IFN-y production by Toxoplasma-specific T cell lines. The proliferative responses of the $T$ cell lines obtained from subjects with recent toxoplasmosis and latently infected individuals were antigen specific. Only toxoplasma antigen and ACs caused proliferation, whereas incubation of the lines with ACs alone (table 4) or with ACs and tetanus toxoid (data not shown) yielded no stimulation. Unseparated PBLs from three of five individuals showed strong proliferation in response to tetanus toxoid (data not shown).

With use of limiting dilution, Toxoplasma-specific sublines highly enriched for one marker (either T4 or T8) were obtained (table 4 ). In one subject with recent toxoplasmosis (A2), SL1, depleted of T8positive cells, showed significantly higher proliferation than the parent line, which contained $73 \%$ T8positive cells, and SL2, which had 99\% T8-positive cells. Similarly, in one chronically infected individual (B2), T8-depleted SL1 (0\% T8-positive cells) proliferated more than the parent line, with $30 \%$ T8-positive cells, and SL2, with only 7\% T4-positive cells.

Two lines obtained from subject $\mathrm{C}$, which contained very low numbers of $\mathrm{T} 8$ cells $(9 \%$ and $3 \%)$, showed high SI values (38-and 33-fold). These data suggest that an inverse correlation exists between the magnitude of proliferation of toxoplasma anti. 
Table 3. Percentages of T8- and TQ1-positive cells in Toxoplasma-specific T cell lines.

\begin{tabular}{|c|c|c|c|c|c|}
\hline Subject & $\begin{array}{l}\text { Antigen }(\mu \mathrm{g} / \mathrm{ml}) \\
\text { used for induction }\end{array}$ & $\mathrm{T} 8(\%)$ & TQ1 ( $\%)$ & $\begin{array}{c}\mathrm{T} 4 / \mathrm{T} 8 \\
\text { (blood)* }\end{array}$ & $\begin{array}{l}\text { IgG titer } \\
\text { (serum) }\end{array}$ \\
\hline \multicolumn{6}{|c|}{ Symptomatic toxoplasmosis } \\
\hline \multirow[t]{2}{*}{ A1 (2 months ago) } & 100 & 43 & 63 & 0.5 & $1: 3,200$ \\
\hline & 10 & 62 & 54 & & \\
\hline \multirow[t]{2}{*}{ A2 (21 months ago) } & 100 & 73 & NT & 2.2 & $1: 160$ \\
\hline & 10 & 68 & NT & & \\
\hline \multicolumn{6}{|l|}{ Asymptomatic infection } \\
\hline \multirow[t]{2}{*}{ B1 (years ago) } & 100 & 40 & 32 & 2.0 & $1: 160$ \\
\hline & 10 & 31 & 38 & & \\
\hline B2 (years ago) & 100 & 30 & NT & 1.1 & $1: 320$ \\
\hline \multirow{2}{*}{ C. (9 years ago $)$} & 50 & 9 & NT & NT & $1: 25,600$ \\
\hline & 5 & 3 & NT & & \\
\hline
\end{tabular}

NOTE. T cell lines induced with toxoplasma antigen $(5-100 \mu \mathrm{g} / \mathrm{ml})$ and demonstrated to proliferate specifically with the antigen were tested with monoclonal antibodies (to T8, a cytotoxic/suppressor cell marker, and to TQ1, a marker of suppressor cell subsets) with use of indirect immunofluorescence.

* T4/T8 (helper/suppressor) cell ratios were measured in peripheral blood at the beginning of the $T$ cell line induction.

$\dagger$ The titer of IgG antibody to Toxoplasma was measured with use of indirect immunofluorescence.

gen-specific $T$ cell lines and the number of $T 8$ positive cells that they contain.

Table 4 shows the production of IFN- $\gamma$ by T cell sublines enriched for one cell type. The two sublines obtained from subject $\mathrm{A} 2$, with a history of prolonged disease syndrome that started 21 months ago, produced low levels of IFN- $\gamma(10$ and $80 \mathrm{U} / \mathrm{ml})$ after antigen stimulation. None of the six $T$ cell sublines obtained from an asymptomatic individual (subject B2) showed such low levels. Stimulation with the mitogen PHA of lines that produced low levels of IFN- $\gamma$ in response to antigen induced high levels of IFN- $\gamma$. T4 cell sublines (A2 SL1 and B2 SL1), one non-T4 subline (B2 SL2), and all uncharacterized

Table 4. Proliferation and IFN-y production by Toxoplasma-specific $\mathrm{T}$ cell lines and sublines.

\begin{tabular}{|c|c|c|c|c|c|c|}
\hline \multirow{2}{*}{$\begin{array}{l}\text { Subject, line or } \\
\text { subline (antigen dose)* }\end{array}$} & \multicolumn{2}{|c|}{$\begin{array}{l}\text { Proliferation } \\
\text { (cpm) with }\end{array}$} & \multicolumn{2}{|c|}{ T8-positive cells } & \multicolumn{2}{|c|}{$\begin{array}{c}\text { IFN- } \gamma \\
(U / \mathrm{ml}) \text { after }\end{array}$} \\
\hline & ACs plus antigen & ACs alone & Percentage & SI & Antigen & PHA \\
\hline \multicolumn{7}{|l|}{ A2 } \\
\hline$P(100)$ & $16,663 \pm 1,534$ & $3,940 \pm 492$ & 73 & 10 & 20 & NT \\
\hline SL1 (50) & $71,335 \pm 5,515$ & $83 \pm 32$ & 1 & 859 & 80 & 500 \\
\hline SL2 (50) & $4,631 \pm 762$ & $504 \pm 106$ & 99 & 9 & 10 & 700 \\
\hline \multicolumn{7}{|l|}{ B2 } \\
\hline$P(100)$ & $7,811 \pm 2,107$ & $932 \pm 315$ & 30 & 8 & NT & NT \\
\hline SL1 $(50)$ & $10,614 \pm 17$ & $173 \pm 49$ & 0 & 61 & 700 & NT \\
\hline SL2 (50) & $5,390 \pm 565$ & $1,219 \pm 98$ & $\dagger$ & 4 & 1,400 & NT \\
\hline SL3 (50) & $15,886 \pm 4,815$ & $1,187 \pm 146$ & NT & 13 & 240 & NT \\
\hline SL4 (50) & $4,399 \pm 157$ & $77 \pm 25$ & NT & 57 & 500 & NT \\
\hline SL5 (50) & $3,220 \pm 591$ & $82 \pm 7$ & NT & 34 & 150 & NT \\
\hline SL6 (50) & $2,480 \pm 319$ & $330 \pm 67$ & NT & 8 & 500 & NT \\
\hline \multicolumn{7}{|l|}{$\mathrm{C}$} \\
\hline P1 (50) & $12,162 \pm 1,499$ & $319 \pm 235$ & 9 & 38 & 150 & NT \\
\hline $\mathrm{P} 2(5)$ & $16,425 \pm 440$ & $494 \pm 63$ & 3 & 33 & 1,400 & NT \\
\hline
\end{tabular}

NOTE. Subject A2 was a patient with symptomatic toxoplasmosis, subject B2 was an asymptomatic patient with chronic toxoplasma infection, and subject $C$ was an asymptomatic patient with Hodgkin's disease in remission. Data are mean \pm SD values as indicated. $\mathrm{P}=$ parent line; $\mathrm{SL}=$ subline, enriched by limiting dilution for one cell type; and $\mathrm{SI}=$ stimulation index.

* Toxoplasma antigen in $\mu \mathrm{g} / \mathrm{ml}$ used to induce the line.

$\dagger$ SL2 contained 7\% T4-positive cells; T8-positive cells were not tested. 
sublines from an asymptomatic patient (B2 SL3-6) produced IFN- $\gamma$ after stimulation with toxoplasma antigen. Stimulation of the sublines with purified protein derivative did not cause production of IFN$\gamma$ (data not shown). These antigen-specific sublines may reflect true production of IFN- $y$ because they do not contain significant numbers of undefined cells that could consume lymphokine [13]. Nonenriched $\mathrm{T}$ cell lines (i.e., mixed $\mathrm{T}$ cell lines) from all individuals studied that were induced with a high dose of toxoplasma antigen $(50-100 \mu \mathrm{g} / \mathrm{ml})$ demonstrated low production of IFN- $\gamma$, whereas lines induced with lower antigen doses $(5-10 \mu \mathrm{g} / \mathrm{ml})$ produced higher amounts. This variability is very likely a result of conflicting influences on production and consumption of IFN- $\gamma$ by undefined cells. The line from subject $C$ that contained only $3 \% \mathrm{~T} 8$-positive cells produced the highest amounts of IFN- $\gamma, 1,400 \mathrm{U} / \mathrm{ml}$ (table 4), of all nonenriched lines studied.

\section{Discussion}

Observations reported here indicate that marked alterations in antigen-specific $T$ cell populations and in monocyte numbers occur during the first months after symptomatic infection with Toxoplasma. The alterations include high numbers of total cells positive for T8, Leu 7, and both T8 and Leu 7, decreased $T 4 / T 8$ cell ratios, high numbers of monocytes in peripheral blood, and a high percentage of $\mathrm{T} 8$ - and TQ1-positive cells in toxoplasma antigen-induced $T$ cell lines. The abnormalities in total peripheral blood T cell subsets were seen as late as six months, but not 20 months, after symptomatic illness, whereas high numbers of T8-positive cells in antigen-inducer $\mathbf{T}$ cell lines were seen as late as $\mathbf{2 1}$ months after infection in one individual. In contrast, chronically infected subjects had normal numbers of T8-positive cells, normal T4/T8 cell ratios, and fewer T8-positive cells in response to toxoplasma antigen in $\mathrm{T}$ cell lines.

Two reports $[14,15]$ have shown similar changes in peripheral blood $T$ cell subsets during toxoplasmosis. De Waele et al. [14] studied one recently infected patient with toxoplasmosis, Luft et al. [15] studied six patients, and we now add eight more patients, all of whom showed an increase in number of T8-positive cells in peripheral blood. In the present study asymptomatic patients infected chronically with Toxoplasma were also evaluated, and they showed peripheral blood $\mathrm{T}$ cell populations similar to those of control subjects. Luft et al. [15] studied four patients who were asymptomatic although recently infected. These individuals also showed normal numbers of T8-positive cells, which distinguished them from the symptomatic patients studied by Luft et al. [15] and by us. This single observation raises the possibility that an increase in number of T8-positive cells is a correlate of the disease state and not simply indicative of recent infection. Two of our patients provide some support for a relation between symptomatic infection and PBL abnormalities.

The illness, lymphatic toxoplasmosis, may be considered an immunologic disease initiated in some individuals by the infectious process. T. gondii is similar to the two viruses known to cause mononucleosis, Epstein-Barr virus and cytomegalovirus, in that both lymphadenopathy and increased numbers of T8positive cells in the peripheral blood have been recorded $[16,17]$. Similar to the cases reported here, the abnormalities in lymphocyte subsets caused by cytomegalovirus have persisted up to 10 months after infection [17]. Prolonged abnormalities in lymphocyte subsets have recently been observed during acute infections with retrovirus [18]. It has not been possible to elucidate the reasons for the changes in $\mathrm{T}$ cell subsets during these infections.

This is the first study of the populations of cells seen in response to toxoplasma antigen in individuals with recent, symptomatic, or chronic asymptomatic infections. The increased antigen-specific selection of T8-positive cells suggests that the altered ratios of total $T$ cells are due to antigen-specific response patterns. Large numbers of T8-positive cells were generated in subjects with recent toxoplasmosis, unrelated to the antigen dose used. In vitro proliferation was toxoplasma antigen specific, and it tended to be highest in cell cultures with a predominance of T4-positive cells. A correlation of predominance of T4-positive cells after induction with toxoplasma antigen, enhanced in vitro proliferation in response to antigen, and high serum titers of antibody was demonstrated in one individual (subject C) with a history of Hodgkin's disease and infection with Toxoplasma. The data, based on a few subjects, suggest the possibility that the T8-positive cells observed to be increased during toxoplasmosis may modulate the proliferation of T4-positive cells to toxoplasma antigen in vitro and the magnitude of the humoral response to Toxoplasma in vivo. Although antigen-specific T8-positive suppressor cells have been described [19], the mechanisms of the suppression are unknown [20-23]. The finding of in- 
creased numbers of TQ1-positive cells (a marker described on suppressor $T$ cell subsets) $[7,12]$ in $T$ cell lines induced by toxoplasma antigen from a symptomatic subject supports the view that $T$ cells with a negative immunoregulatory role are induced by this antigen.

Antigen-induced T8-positive cells may also occur in individuals infected with Epstein-Barr virus, cytomegalovirus, and retrovirus, although studies of these viral infections similar to those described here have not been done. Antigen-specific immunity to herpes simplex virus type 2 has been studied in individuals in various phases of infection [24].

The mechanism responsible for selection of T8positive cells is unknown. It does not appear to be dependent on antigen dose because both 10 and 100 $\mu \mathrm{g} / \mathrm{ml}$ induced large numbers of T8-positive cells in subjects with recent toxoplasmosis. Antigen fractionation must be done to determine whether some toxoplasma antigens are more likely than others to induce this response in vitro. Our data suggest that even after total $T$ cell ratios are normal, antigen-specific induction still favors T8- over T4-positive cells. Long after infection, individuals appear to have the network for protective immunity with rapidly proliferating, functioning T4-positive cells.

Enhancement of NK cell activity has been described in the mouse model [25] and in human lymphocyte cultures [26] in response to toxoplasma antigens. In humans with acute symptomatic toxoplasmosis, we found increased numbers of circulating cells carrying the marker of NK and $\mathrm{K}$ cells (Leu $7 /$ HNK 1). Such cells could be associated with killing of parasite-infected cells via antibody-dependent cell-mediated cytotoxicity [27], or they may contribute additional down regulation of the immune response because Leu 7-positive suppressor cells have been described [28]. In addition, two subjects with acute toxoplasmosis had increased numbers of cells carrying a dual marker of cytotoxic cells (T8) and of NK cells (Leu 7). Leu 7-positive cells carrying simultaneously the T8 cell marker have been described as immature bone marrow NK cells [29].

The Toxoplasma-infected subjects in this study had, in addition to the changes in lymphocyte subsets, increased numbers of monocytes in peripheral blood up to the second month after infection. This finding is of interest because toxoplasmosis in animal models has been found to be associated with increased numbers of monocytes and macrophages at various sites [1, 30, 31] (T.C.J., S.A., and P.E., un- published observation) and in degree of activation [30]. Because $T$ cell regulation of the myelopoiesis by production of monocyte colony-stimulating factors after specific antigenic stimulation of cloned $T$ cells has been recently demonstrated [32], it is possible that the increased numbers of monocytes in our symptomatic subjects were due to the described expansion of $T$ cell subsets.

We found that cloned $\mathrm{T}$ cells of both the $\mathrm{T} 4$ and the $\mathrm{T} 8$ phenotypes from one symptomatic individual produced less IFN- $\gamma$ after stimulation with toxoplasma antigen compared with $\mathrm{T}$ cells from an asymptomatic individual. This finding may represent (besides increased numbers of T8-positive cells in response to toxoplasma antigen in vitro) another marker that identifies individuals prone to manifest disease. This suggestion is supported by a study that showed that in the course of acute symptomatic toxoplasmosis, one patient's cells' ability to inhibit Toxoplasma was initially impaired [4].

Further studies are needed to determine whether these T8-positive cells are functioning as specific suppressor cells of cell-mediated processes such as $\mathrm{T}$ cell proliferation, as recently suggested by Luft et al. [33], monocyte colony stimulation [32], or specific antibody suppression [19], or whether these cells are expanded cytotoxic cells competing for lymphokines.

All the changes shown are indicative of immunologic imbalance during recent symptomatic toxoplasmosis. The infectious agents studied so far that cause an imbalance of immunoregulatory lymphocyte subsets (Epstein-Barr virus, cytomegalovirus, herpes simplex virus, retroviruses, and $T$. gondii) have one feature in common, namely, they cause a latent, usually life-long infection. These infectious agents appear to be capable of inducing an antigen-specific imbalance of the immunoregulatory network leading to a postinfection immune dysfunction syndrome of varying duration. In toxoplasmosis this syndrome is characterized by signs and symptoms (including lymphadenopathy, fever, and malaise) and by increased numbers of circulating T8-positive/Leu 7-positive cells and monocytes and by impaired production of lymphokines (IFN- $\gamma$ ) by antigenspecific $\mathrm{T}$ cells. The factors that contribute to emergence of this syndrome in one of five Toxoplasmainfected individuals remain undefined.

\section{References}

1. Jones TC. Immunopathology of toxoplasmosis. Springer Semin Immunopathol 1980;2:387-97 
2. Ruskin J, Remington JS. Toxoplasmosis in the compromised host. Ann Intern Med 1976;84:193-9

3. Anderson SE Jr, Krahenbuhl JH, Remington JS. Longitudinal studies of lymphocyte response to toxoplasma antigen in humans infected with $T$. gondii. J Clin Lab Immunol 1979;2:293-7

4. Johnson WD Jr. Chronological development of cellular immunity in human toxoplasmosis. Infect Immun 1981; 33:948-9

5. Abo T, Cooper MD, Balch CM. Postnatal expansion of the natural killer and killer cell population in humans identified by the monoclonal HNK-1 antibody. J Exp Med 1982;155:321-6

6. Hoffman RA, Kung PC, Hansen WP, Goldstein G. Simple and rapid measurement of human $T$ lymphocytes and their subclasses in peripheral blood. Proc Natl Acad Sci USA 1980;77:4914-7

7. Reinherz EL, Morimoto C, Fitzgeral KA, Hussey RE, Daley JF, Schlossman SF. Heterogeneity of human $\mathrm{T}^{+}$inducer $T$ cells defined by a monoclonal antibody that delineates two functional subpopulations. J Immunol 1982;128:463-8

8. Schreier MH, Tees R. Long term culture and cloning of specific helper T cells. In: Lefkovitz I, Pernis B, eds. Immunological methods. Vol. 2. New York: Academic Press, 1981:263-75

9. Pauly JL, Russell CW, Planinsek JA, Minowada J. Studies of cultured human T lymphocytes. I. Production of the $\mathrm{T}$ cell growth-promoting lymphokine interleukin-2. $\mathrm{J} \mathrm{Im-}$ munol Methods 1982;50:173-86

10. Jones TC, Len L, Hirsch JG. Assessment in vitro of immunity against Toxoplasma gondii. J Exp Med 1975;141: 466-82

11. Armstrong JA. Semi-micro, dye-binding assay for rabbit interferon. Applied Microbiology 1971;21:723-5

12. Morimoto C, Distaso JA, Cheney JJ, Reinherz EL, Schlossman SF. Cellular interaction between subsets of T8 population for maximal suppression of antigen-specific antibody response. Cell Immunol 1984;88:75-84

13. Lotzová E, Savary CA. Stimulation of NK cell cytotoxic potential of normal donors by two species of recombinant alpha interferon. J Interferon Res 1984;4:201-13

14. De Waele $M$, Thielemans $C$, Van Camp B. Immunoregulatory $\mathrm{T}$ cells in mononucleosis and toxoplasmosis [letter]. N Engl J Med 1981;305:228

15. Luft BJ, Kansas G, Engelman EG, Remington JS. Functional and quantitative alterations in $T$ lymphocyte subpopulations in acute toxoplasmosis. $J$ Infect Dis 1984;150:761-7

16. De Waele M, Thielemans C, Van Camp BKG. Characterization of immunoregulatory $T$ cells in EBV-induced infectious mononucleosis by monoclonal antibodies. $\mathrm{N}$ Engl J Med 1981;304:460-2

17. Carney WP, Rubin RH, Hoffman RA, Hansen WP, Healey $\mathrm{K}$, Hirsch MS. Analysis of $\mathrm{T}$ lymphocyte subsets in cytomegalovirus mononucleosis. J Immunol 1981;126: 2114-6

18. Cooper DA, Maclean P, Finlayson R, Michelmore HM, Gold J, Donovan B, Barnes TG, Brooke P, Penny R. Acute AIDS retrovirus infection. Definition of a clinical illness associated with seroconversion. Lancet $1985 ; 1: 537-40$
19. Morimoto C, Reinherz EL, Todd RF, Distaso JA, Schlossman SF. Generation of antigen-specific suppressor cells in vitro in man. $\mathrm{J}$ Immunol 1983;131:1209-13

20. Reinherz EL, Hussey RE, Fitzgerald K, Snow P, Terhorst C, Schlossman SF. Antibody directed at surface structure inhibits cytolytic but not suppressor function of human $T$ lymphocytes. Nature 1981;294:168-70

21. Moretta A, Pantaleo G, Moretta L, Mingari MC, Cerottini J-C. Quantitative assessment of the pool size and subset distribution of cytolytic $\mathrm{T}$ lymphocytes within human resting or alloactivated peripheral blood $\mathrm{T}$ cell populations. J Exp Med 1983;158:571-85

22. Moretta A, Pantaleo G, Maggi E, Mingari MC. Recent advances in the phenotypic and functional analysis of human T lymphocytes. Semin Hematol 1984;21:257-69

23. Günther J, Haas W, von Boehmer H. Suppression of $T$ cell responses through competition for $T$ cell growth factor (interleukin 2). Eur J Immunol 1982;12:247-9

24. Sheridan JF, Donnenberg AD, Aurelian L, Elpern DJ. Immunity to herpes simplex virus type 2 . IV. Impaired lymphokine production during recrudescence correlates with an imbalance in T lymphocyte subsets. J Immunol 1982; 129:326-31

25. Hauser WE Jr, Sharma SD, Remington JS. Augmentation of NK cell activity by soluble and particulate fractions of Toxoplasma gondii. J Immunol 1983;131:458-63

26. Sharma SD, Verhoef J, Remington JS. Enhancement of human natural killer cell activity by subcellular components of Toxoplasma gondii. Cell Immunol 1984;86:317-26

27. Herberman RB. Natural killer (NK) cells and their possible roles in resistance against disease. Clin Immunol Rev 1981;1:1

28. Tilden AB, Abo T, Balch CM. Suppressor cell function of human granular lymphocytes identified by the HNK-1 (Leu 7) monoclonal antibody. J Immunol 1983;130:1171-5

29. Abo T, Cooper MD, Balch CM. Characterization of HNK$1^{*}$ (Leu-7) human lymphocytes. I. Two distinct phenotypes of human NK cells with different cytotoxic capability. J Immunol 1982;129:1752-7

30. Krahenbuhl JL, Remington JS. The immunology of Toxoplasma and toxoplasmosis. In: Cohen S, Warren KS, eds. Immunology of parasitic infections. 2nd ed. Oxford: Blackwell, 1982:356-421

31. McLeod R, Estes RG, Mack DG, Cohen H. Immune response of mice to ingested Toxoplasma gondii: a model of toxoplasma infection acquired by ingestion. $J$ Infect Dis 1984;149:234-44

32. Griffin JD, Meuer SC, Schlossman SF, Reinherz EL. T cell regulation of myelopoiesis: analysis at a clonal level. J Immunol 1984;133:1863-8

33. Luft BJ, Remington JS. Functional abnormalities of lymphocyte subsets in patients with acute toxoplasma infection [abstract 621]. In: Program and abstracts of the 24th Interscience Conference on Antimicrobial Agents and Chemotherapy. Washington, DC: American Society for Microbiology, 1984 